\title{
9 \\ Blasphemy in a pluralistic society
}

\author{
Jeremy Shearmur
}

In this chapter, I will tentatively address a difficult issue: what we should make of blasphemy today, in a society like Australia? ${ }^{1}$ My discussion falls into three parts: considering blasphemy under the headings of truth, ridicule, and play. I also discuss some different dimensions to the character of the offence. I conclude with a discussion of some particular problems about blasphemy posed by the fact that we are living in a pluralistic society, in the face of which I make some specific — but inadequate - recommendations. I am happy to call them 'inadequate' just because my aim, at the end of the paper, is to open up what seem to me some difficult problems rather than to resolve them.

In my preparatory research, I came to the conclusion that the more that one looks at some of the issues connected with blasphemy, say, at their history, the more complex they turn out to be. The consequence is that if, as in the present chapter, one is trying to speak in general terms, one becomes acutely aware of just how thin the ice is upon which one is treading. As a result, it is bound to be the case that, in addition to provoking the kind of critical reaction that I am intending to provoke, and which I am hoping will lead to a fruitful response to the issues which I am setting out to raise, I may also provoke all kinds of gnashing of teeth on the part of those who have specialised knowledge on issues that I deal with very briefly. All that I would say in my defence is that I am acutely aware of my fallibility and, as a former student of Karl Popper's, I am aware of the need for criticism, which I look forward to receiving in due course.

Let me start by saying a very little about a key problem. It is: What is the character of blasphemy as an offence, and why was it thought appropriate to punish it? My concern here will not be with its legal status, ${ }^{2}$ but with what the underlying concerns have been. There seem to me to have been several lines of argument. I will mention but five.

The first, as, say, we meet it for example in Leviticus 24, 16-18, is that the punishment, even with death, of the blasphemer is simply seen as a command of God, which is to be followed as such.

The second is that blasphemy is understood as a substantive offence against God. Here, humans who make accusations of it, and uphold the law in relation to it are, as it were, acting in His defence, or in defence of His reputation. 
The third is slightly convoluted. It is that blasphemy is understood as something which, if unpunished, will threaten those who do not punish it with the judgement of God. Punishment of the blasphemer is, here, seen as a reaction to the threat of the collective punishment by God of those who fail to punish blasphemer.

The fourth is the idea that an attack on religion is problematic because of what are thought to be its social consequences, i.e., the destruction of civil order. This played a significant role during one period of British law, as is illustrated by the following statement by Lord Chief Justice Hale:

...to say, religion is a cheat, is to dissolve all those obligations whereby the civil societies are preserved, and that Christianity is parcel of the laws of England; and therefore to reproach the Christian religion is to speak in subversion of the law. ${ }^{3}$

Finally, there is a more typically modern understanding. This is the notion of blasphemy as an offence against the sensibilities of believers, and, further, as something which because it so offends, is problematic because it is liable to lead to a breach of the peace.

Let me now move to the discussion of blasphemy, as such. I need briefly to explain why I am discussing the issue of blasphemy under the three heads to which I have referred: truth, ridicule and play. ${ }^{4}$ I do so because, historically, one can note people as having been charged with blasphemy for activities that fall conveniently under these somewhat different headings, and I wish to argue that the issues that they raise are somewhat different, too.

Historically, one element in blasphemy has been a simple contesting of the truth of various religious claims. This, for example, was one element in the charges against Thomas Aikenhead at the end of the seventeenth century and against G. W. Foote in the latter part of the nineteenth. In earlier times, people who had wished to contest the truth of Christianity, were sometimes punished - but for impiety. In the context of an orthodox Christianity feeling under threat from Socinianism and Deism, ${ }^{5}$ Aikenhead's youthful mixture of contestation of and irreverent comment about Christianity was taken horribly seriously, and he was executed. ${ }^{6}$ Foote, the editor of The Freethinker in the 1880s, combined denial of the truth of Christianity, and fierce argument to that effect, with the use of ridicule. ${ }^{7}$ In the context of one of the trials of The Freethinker, Lord Coleridge declared:

I lay it down as law, that, if the decencies of controversy are observed, even the fundamentals of religion may be attacked without a person being guilty of blasphemous libel. ${ }^{8}$ 
This is generally accepted in Western countries today; but, for example, it may be contentious for some Muslims. Foote, however, did much more than this. And that takes us to the second category, of ridicule. One of the features of The Freethinker were various hostile cartoons about the life of Jesus, and more generally illustrating in a satirical manner various themes from the Bible. The latter included an unsubtly illustrated version of the verse from Exodus 33, verses 22-3: 'And it shall come to pass...that I will put thee in a clift of the rock... and I will take away my hand and thou shalt see my back parts' ${ }^{9}$ The Freethinker's cartoon, as the previous quotation from Lord Coleridge implicitly indicated, raises the issue: Is the use of ridicule as part of an attack on religion acceptable?

Third, and of particular significance in our current context, is what I will term the playful or aesthetic use of blasphemy. By this I mean blasphemy committed not as part of a disagreement with, or an attack on religion (although it is not clear that it would be used in such a manner by a devout religious believer), but, instead, as used for literary or artistic effect. An obvious example here is Salman Rushdie's playing with themes from Islam to literary effect, in his Satanic Verses. We may here, similarly, consider the work of art, Piss Christ, and also, say, in a much more minor key, parodies of the Creed, and so on, produced by William Hone for political purposes in the early nineteenth century. ${ }^{10}$ The key idea here is that religious material is played with, or used for effect, in ways that believers could reasonably find offensive, but where the motivation of those making use of this material is not to attack religion. With this before us, let me now turn to the body of the paper, and to the issue of truth.

\section{Truth}

Truth seems to me usefully looked at in terms of the kinds of consideration that John Stuart Mill advanced in his On Liberty. I should state explicitly that my concern, here, will be with the social consequences of epistemological fallibilism ${ }^{11}$ rather than with the specifics of Mill's views; Jonathan Riley has argued powerfully that Mill's own arguments are best seen in the wider context of his social philosophy, and that seen in that light, Mill is to be taken as arguing for a more liberal view than that which is presented here. ${ }^{12}$ If it is being claimed that various religious doctrines are true, then some kind of case has to be made for them. What is involved here, may seem to get us into the territory of various traditional arguments for the existence of God, such as the 'cosmological argument'. But what is actually offered in the context of religious proselatisation may be rather different.

Now if any such claims are being made as to the truth of religious doctrine, we get straight into the issues which J. S. Mill discussed. ${ }^{13} \mathrm{He}$ argued that all 
of our knowledge is fallible, and that if we are aiming for truth, our best course of action is to submit our claims to open critical scrutiny. In this context, he was then able to develop arguments against the suppression of opinion. To Mill's argument, it might be objected by the believer: 'but our religious views are not fallible'. However, those who agree with Mill can respond: 'but you have certainly not furnished us with telling arguments that show you views to be anything but fallible. ${ }^{14}$ And your tendency, across history, to kill or to imprison those who have objected to your claims, does not exactly speak for their strength - for if the arguments were strong, why should they require support from the hangman or the jailor'. ${ }^{15}$

It seems to me that, here, the case for allowing the public contestation of religious doctrines is unanswerable. Not only is the Millian case a powerful one, but since the Reformation we have lived in a society in which religious truth is contested. If there are Catholics and Protestants - to say nothing of Muslims and Jews, and also non-believers - who are members of a single society, then clearly there is disagreement about religious truth. ${ }^{16}$ Indeed, the very beliefs of these groups implicitly or sometimes even explicitly involve the view that the other religious beliefs are incorrect. If we are living in a society that is pluralistic in this sense, the notion that the discussion and the contestation of religious ideas should be suppressed would seem an absurdity. (It is, however, worth noting that Jewish criticism of Christian claims, particularly its claims about itself as a supposed fulfilment of the Old Testament, was frequently suppressed. ${ }^{17}$ ) Given that all the groups to whom I have referred contemporary Judaism apart - are universalistic and attempt to convert others, this is surely an invitation to contestation. ${ }^{18}$

Today, Christendom accepts the case for openness of argument. (Although one wonders sometimes what the more dogmatic believers would do, if they could get their hands on the reins of enough political power.) It is not clear that this case for openness of argument is accepted by all Muslim clerics. Attitudes there, at least in terms of the views of some clerics, seem closer to those that were common in Western countries several centuries ago, although there are, of course, also liberal Muslims. There is also room for debate as to just what is supposed to be accorded what kind of protection, and it is quite another matter what anyone actually becomes concerned about (the Rushdie case had strong political elements to it). At least in principle, to voice disagreement about some key issues is problematic, even if all that is involved is intellectual engagement. Of course, in practical terms, no Muslim is going to be able legally to take action against Christian ministers who may say things within their religious congregations that are at odds with Islam. Further, Muslims have, I think, to face the fact that if they choose to live in a society like Australia, they are living in a society in which the open intellectual contestation of their beliefs - whether 
by sceptics, or by those who favour other religions - will take place. Further, if such contestation is conducted along the 'decent' lines that Lord Coleridge suggested, other citizens will expect that those engaged in such contestation will, if necessary, receive full protection from the law.

\section{Some limitations of the truth-based argument}

It is, however, worth pausing to consider what the intellectual issues to which I have referred actually amount to. For this intellectual case has limitations; in particular, it does not seem to me to offer the basis of a case for 'freedom of expression'. (Clearly, someone might say: 'but the case for freedom of expression does not depend on arguments like Mill's, but, instead, relates somehow to ideas about human agency, or is simply a "right". . But it is just not clear on what basis such a right could be established if, say, it involves a purported entitlement to behave in offensive ways towards others.)

Let me return to the fallibilistic argument from Mill. As far as I can see, all that is required for the fulfilment of the kinds of requirement that Mill set out, is that there be some place where such contestation can take place, and that the results of debates about such matters be freely available in the society. ${ }^{19}$ What this means, is that there need to be journals in which such matters can be discussed, and places where people interested in such things can meet. This is a very different matter from some entitlement to bombard other people with challenges to their views when they do not wish to encounter them, ${ }^{20}$ or, say, a right even to demonstrate as opposed simply to the advancing of arguments. More generally, an awareness of human fallibility seems to me in principle compatible with restrictions on the dissemination of information which has not been exposed to some appropriate form of inter-subjective scrutiny. This might, however, today be accomplished without the suppression of opinion, by way of the requirement that certain kinds of material be published only in a setting in which an indication can be given of the basis on which others disagree with what is being advanced. For example, rather than the making of claims about, say, holocaust revisionism illegal — which may itself backfire ${ }^{21}$ — there could be a legal requirement that the material be posted only to web pages that allow for responses by scholars who disagree with the case being argued.

Let me also offer some further considerations against the taking of Millian arguments in an expansive way. There is much that goes to constitute our day-to-day lives that might quite fairly be called necessary fictions. We typically have a view of the world, and of ourselves, which we implicitly take to be correct and live by, and which we are not interested in having challenged. Most people, if they are not suffering from depression, are moral heroes in their own internal narratives; and all of us operate within a framework of assumptions - many of which will not, in fact, be true - which we certainly do not wish to have challenged, unless we choose to open them up to such challenges. Some of those 
reading this will, like myself, be academics, and this means that certain things that we do will be subject to fairly constant challenge and criticism. More generally, the cultures in which academics live and by which our ideas are broadly informed are subject to certain kinds of challenge and scrutiny. But typically — and, I think, quite properly - the ideas that constitute the assumptions under which we live on a day-to-day basis, are not usually submitted to such scrutiny. In part, this is because one can, as it were, hardly live in the open - with all aspects of ourselves and our conduct exposed to the critical scrutiny of others all the time. In part, it is because many of these ideas are simply things that we use while getting on with other, more pressing, matters. At the same time, one of the features of life in Australia which I have come to value - as compared, say, to the USA - is that there is a degree of accountability here to one another, in our ordinary culture, for what we believe. ${ }^{22}$

Now, the ideas on the basis of which we live may well be incorrect or misguided. Sometimes, we may become annoyed with other people because of what they believe and act on. But broadly speaking, it seems to me that we are not entitled to challenge them (unless we are invited to do so), unless it is the case that those ideas and their actions (or failures to act) impinge significantly upon us, or upon others with whose well-being we have a legitimate concern. In this respect, while intellectual contestation is important, there is no case for the view that one is simply entitled to harangue other people, unasked, about their ideas or view of the world. (Or rather, there is a sense in which one may do this, in respect of people who are friends of ours, provided that they have the option to stop being our friends if they find this wearing!) Such ideas consider, say, whether or not they think that eating meat is wrong - in effect become like the tastes of these other people: things that we simply live with provided that they neither positively harm others in ways that we find intolerable, nor make us really uncomfortable. If they harm others, ${ }^{23}$ we may feel it our duty to open up a discussion about them. If they simply make us uncomfortable, we may need to modify how we interact with these people (for example, just moaning about them to friends who agree with us), or possibly even break off contact with them.

This may seem a somewhat timid viewpoint, and you may even object to it. But if you do, just ask those who know you, how many of your views about things they think to be incorrect, and ask yourself: 'would I like to be constantly open to contestation about them?' Alternatively, you may yourself be committed to some form of proselytisation; for example, for some religious view, or for some form of environmentalism. If this is the case, it is worth bearing in mind just to what extent you may be infringing upon the kinds of informal rules that we normally live by concerning such matters, and thus pausing to consider just how obnoxious you may be. If you are going to do this, however, it seems to me that what is good for the goose is good for the gander. You should recognise 
that not only may people (understandably) start to avoid you, but you may legitimately expect them to make you aware of the range of objections to your views, if they are not too polite to do so.

This is a somewhat difficult matter. For consider, say, the Protestant who thinks that if you are not saved, you will suffer in Hell. ${ }^{24}$ How, such a person might say, can they be expected to conduct the ordinary niceties of life with you, without drawing this to your attention - and repeatedly, because so much hinges on it? They would surely do this, if you were in physical danger; and how much more important is your fate in Eternity? But just as that person may feel that he or she cannot engage in polite social chit-chat with those on the edge of a precipice, so the objects of their concern may find that they really cannot take constantly being engaged with on this subject. The only courses of action may be to agree not to raise the issue, or to separate.

There is, however, also another aspect to all this. It is that, as academics who are used to the cut and thrust of discussion, we typically come to know what we are letting ourselves in for if we enter into it. For each of us, there will be certain kinds of standards to which we know that we will be held accountable in our various professions and the sub-areas of these that we inhabit. I can, by now, make a pretty fair judgement as to what the (different) standards are, to which different groups of philosophers, of political scientists, of historians of economic thought, and so on, will hold me accountable if I give a paper to them. Further, if I make some claim — say, about the arts — in a gathering of people who deal with the arts professionally, while I cannot judge quite how what I say will be appraised, I will have at least a rough idea about the kinds of things that might be thrown at me.

Such knowledge, however, is typically acquired by us gradually through our lives, and sometimes somewhat painfully. I can still recall coming to university, as a gauche young man who simply did not know how these things worked, and how painful the first few steps were. I have also had the (at times difficult) experience of operating within different disciplinary contexts. By contrast with all this, we may forget that other people may not have this kind of experience behind them. As, say, we are sometimes reminded when a capable but academically inexperienced mature student joins an introductory course in the subject that we teach, people may have specific views which they believe to be true, but where their asserting them as true does not mean quite what it would normally in academic contexts. If I make claims that I assert to be true, this opens me up as an Aunt Sally, for everyone to have a go at. If people do not have an academic background, they may not realise what they are getting into if they make similar claims in an academic context. But, on the other hand, unless we are anthropologists or sociologists with an interest in these issues, we are 
not likely to have any real knowledge as to how their claims about the status of such views are made and negotiated in different areas of even our own society.

I would, in this kind of situation, suggest that we should exercise something the name of which I hardly dare speak, namely, paternalism. That is to say, it seems to me that, unless it is clear that the people in question wish to have their ideas contested as we would have our claims contested, their views be treated more like the expression of tastes. This will typically not be fully adequate to the cognitive character of those views, and there is a risk that we may be insulting to them. But perhaps better this, than the exposure of their ideas to the full force of the critical apparatus that we, given our training, may be able to bring to bear upon them. This, while fully legitimate in its place, may be inappropriate if used in a contest in which people are not accustomed to it, or do not realise what they are getting themselves into. I am reminded of a conversation that a good friend of mine reported that he had with his partner. They had some disagreement about their personal affairs, and he said to her: 'We should talk this out.' She said: 'No way - you, as a philosophy lecturer, are a specialist in arguments. I would not have a chance, even if I was right about everything.'

Just as in this case, it seems to me that in the kind of situations about which I have been talking, respect for other people as persons may mean that we should treat their views as having a somewhat different status from what they may present them as having. After all, we may be quite used to discovering that ideas which we have cherished, and have worked on for a while, turn out just to be no good. Given our professional training, we typically have the resources to cope with such things, even though the experience may not be pleasant. However, it may not be something that other people, without these resources, can easily cope with at all. It is certainly not clear to me why coping with it should be thrust upon them, without their indicating positively that they wish to get into such a situation.

Accordingly, there seems to me a case for the protection of some ideas from criticism - although it is not one which compromises what I might call the minimalist Millian case for there being a public sphere in which any idea may be contested (including, of course, ideas as to what such a sphere should be like). At the same time, it is important to note that the case for the moderation of criticism was made in the face of the vulnerability of the people whom I was discussing, and also under the assumption that what they were doing was not having adverse effects on others. The (interesting) social task here would be to create ways of behaving which protect the vulnerable, but which do not shelter the powerful. 


\section{From intellectual engagement to ridicule}

So far, I have been dealing with issues of truth and falsity, and of the contestation, back and forth, of particular claims. But what of ridicule? Is it ever appropriate to ridicule or to insult things about which other people have deep feelings?

Here, it seems to me, we get onto more difficult ground. For if, say, a Christian believes that God, the all-powerful creator of the universe, gave his Son not only to suffer the humiliations and pangs of mortal life, but to die a gruesome death for the sake of each of us - then to poke fun at this, seems simply grotesque. It certainly is not something that can rest upon a J. S. Mill-style defence. May anything be said in its favour? Two interesting lines of argument here were advanced by the English Freethinker G. W. Foote, who ended up being imprisoned for blasphemy in the 1880s.

First, consider those who are not believers. They may find the hegemony of the ideas to which they are constantly and oppressively exposed, simply intolerable. I recall, here, a comment made by a distinguished sociologist of education, who was Jewish, and who undertook an ethnographic exercise, over a period of three years, in a fundamentalist Baptist school. He later recalled that, he hit a problem:

...in one of the phases of research, the last phase, the write-up. Obviously, my ox had been gored. As a non-Christian at Bethany I experienced repeated proselytising by students, parents, teachers, and the superintendent of the school. I felt that I had been assaulted by the most arrogant people I had ever met in my entire life... Obviously, all of this had gotten to me in more ways tha[n] I understood; it was coming out in my writing, though I didn't want it to. I did not want chapter one, let alone chapter two, three, four, five or six, to be redolent of the anger suggested by terms such as 'assault' and 'arrogance'. ${ }^{25}$

In this case, the sociologist could get away from the group which he had studied. But what if one were a member of a minority group, who were endlessly the targets of something similar from the wider culture?

In this setting, at the very least, it would be fully understandable to let off steam, to other members of one's group, about the kind of things to which one was subjected. This, indeed, was pretty much Foote's explanation for one of the things that his newspaper did: for running his cartoons, poking fun at passages from the Bible. His argument was that the material was sold in a newspaper for Freethinkers; it was not forced upon religious believers, and it would be pretty clear to the believer what the character of the journal was, should they come across a copy. 
Foote, however, offered another line of argument, too. Let me present it, in his own words:

Christians may, of course, urge that their feelings on such a subject as religion are sacred, and a few superstitious Freethinkers may concede this monstrous position. I do not. The feelings of a Christian about Father, Son and Holy Ghost, are no more sacred than my feelings on any other subject. I have no quarrel with persons, and I recognise how many are hurt by satire. But the world is not to be regulated by their feelings, and much as I respect them, I have a greater respect for truth. Every mental weapon is valid against mental error. And as ridicule has been found the most potent weapon of religious enfranchisement, we are bound to use it against the wretched superstitions which cumber the path of progress. Intellectually, it is as absurd to give quarter as it is absurd to expect it. ${ }^{26}$

I do not know what you might make of this. In some ways, for Foote to take this line in a situation where he might well go to jail for it, and indeed did, was courageous. At the same time, it is also clear that such satire need not be on the side of what is right, even though it may be horribly effective. Consider, in this context, the use by the Nazis, and by the regime in the Soviet Union, of art and representations which dehumanised those with whom they disagreed. Not only were those - often very powerful - representations exercised in the interests of views which were, surely, wrong, but they also served to dehumanise people, in ways which opened them to what became ghastly treatment. All told, there seems to me something to be said for treating people with decency, and respecting their sensibilities, even in cases where we think that they are deeply wrong.

Such concerns, however, look to me pressing only in the case of ordinary people, and those who do not exercise power. The powerful can, surely, well look after themselves - although even there, there is surely something to be said for recognising the human in everybody. If we accept this argument, then there is also reason to accord them a certain kind of respect - which would include not submitting those things about which they have the strongest and most tender feelings, to the full force of our abuse.

\section{Play, or the aesthetic use of blasphemy}

So far, our concern has been with those who wish to take issue with the content of religion. But if we consider blasphemy in contemporary contexts, this seems to me not, typically, what we are concerned with. Instead, what has been thought problematic, has been the use of religious ideas for aesthetic reasons or, to put it bluntly, a certain kind of playing around with them.

Consider Salman Rushdie's Satanic Verses. Here, he made a certain amount of mileage, for his own aesthetic purposes, with themes from Islam: the so-called 'satanic verses' episode itself, which related to the supposed interpolation - 
and then deletion when their character as illegitimate interpolations was revealed - of some verses into the text of the Koran, which legitimated the role of some local gods as intermediaries between people and God. In addition, Rushdie played around with the idea of the denizens of an imaginary brothel, who boosted their custom by naming themselves after the wives of the Prophet. Was Rushdie's aim to attack Islam, in something like the way in which Foote did Christianity? Surely not; it was more a matter of his using these ideas, as instruments in his novel. ${ }^{27}$ Similarly, one might say, the artist responsible for Piss Christ was playing around with Christian symbolism.

What is to be said about this? Clearly, there are legitimate uses of religious material, not only in a devotional context, but - because of the extent to which our culture and language is (still) permeated with them - for the purpose of playfulness and parody. Two things, however, are worth noting. First, such usage is parasitic upon the public, cultural significance of the material. The reason why a form of words that draws upon well-known passages from the Bible, or from the Creed, or upon religious symbolism, may make the impression that it does, is because of its resonance with the material from which it is drawn, and the kinds of public associations that it has. Second, there is the problem of the offence that it may cause.

It might be said: 'No offence is intended - the artist had his or her own private intention.' This, however, will not wash, because of the public significance of the material. After all, the aesthetic weight of the material is drawing precisely upon its public, in this case religious, meaning. ${ }^{28}$ What is more, people have to take into account the public meaning of what they are saying. If, say, someone gets up and yells 'Fire, Fire' in a crowded, darkened cinema, it is possible that they may have had their own particular intentions for example, they might be giving an impromptu performance of some free verse. But this is no excuse; unless there is a very distinctive preparation of the people who will be receiving the material, ${ }^{29}$ such that this serves to diffuse its normal social meaning, it is clear how it will be interpreted. And the poet will justly suffer the consequences of their action, if they don't do so.

In the course of the discussion of the Salman Rushdie case, John Updike is reported as having said: 'it is perhaps in the nature of modern art to be offensive...In this century if we are not willing to risk giving offence, we have no claim to the title of artists'. ${ }^{30}$ But bear in mind what it is to be offensive. ${ }^{31}$ First, if someone is offensive to you, they may surely risk retaliation, and if they thought about it, they might well realise that this is what they should expect. Why, after all, should the rest of us be expected to sit there and have people behave offensively towards us, without reacting to it? This, of course, then leads to that element in blasphemy cases in which people are taken to have committed an offence, because their conduct is liable to lead to a breach of the peace. 
Second, being offensive - especially to the defenceless - may simply be a horrible thing to do. Once, say, people understand just what kind of offence certain kinds of conduct, or the improper use of Aboriginal designs, may give to the people in question, it is surely inexcusable to persist in giving offence. It is a horrible action, and also made worse by the sheer lack of power of the people on whom it is inflicted. However, it is not at all clear, say, that the kinds of offence that may be given to ordinary Muslims, or to devout Catholics or to conservative-minded evangelical Christians is any less. Just think, in the latter cases, of how they might experience what is taking place. As I mentioned before, in their view, the creator of the universe chose to humble himself, take on human form and to suffer, so as to bring about the salvation of all who would accept this gift... and this is then mocked, turned into a travesty, or used as a prop for the purposes of comedy. I am not advocating the jailing of the people who might behave in this way. But it seems to me that we should think twice about the idea that such activities can easily be defended as part of a supposed right to self-expression. However, should we go along with such ideas we face a problem; one that I am not sure how to resolve.

\section{Blasphemy in a pluralistic society}

When Salman Rushdie wrote, he knew full well what he was doing. The knowledge that he displayed - in playing around with the 'satanic verses' episode and even in his use of the names of the wives of the Prophet - required some real knowledge of Islam. But it should equally have been clear to him that what he was doing would have been found highly offensive by some Muslims. Clearly, there was much more to the episode than this. There was a strong political element to the attention that his work received, and Muslims could find much other material that would give offence, but which was not singled out for condemnation in this way. Many of his Western readers, however, might have found these aspects of his work unusual, and while - especially if they came across some commentary upon them - they might have been able to understand them, they would surely not have experienced the kind of emotional reaction that some Muslims may have felt.

One obvious problem however, is that now that we are a pluralistic society: in Australia, there are many faiths and sensibilities, and even societies which are relatively homogenous are affected by what is done elsewhere. Just what protections are needed, and what should be protected?

In the face of the Rushdie case, one reaction in the UK was that some Muslims there wished for Rushdie to be had up for blasphemy. They swiftly discovered, however, that in Britain laws against blasphemy related only to the Christian religion - and even, it might appear, to the doctrines of the Church of England. There was, then, a call for the widening of blasphemy law, so that it would apply to other religions. This, however, poses a problem; namely, what should count 
for this purpose. Think about this in an Australian context: Christianity - in all its forms? Islam - bearing in mind that, for Shiites, the twelfth (occluded) Imam would also require protection? Judaism? Aboriginal beliefs? But what about Jehovah's Witnesses, the Mormons, and New Agers, to say nothing of Little Pebble? ${ }^{32}$

There is also a further problem here: namely, just what the content of that which receives such protection will be. It is often - and surely rightly - said that, say, Aboriginal cultures are not static, but evolving. The same, surely, might be the case for what others hold to be Holy. But this poses a problem: if what is so recognised acquires special protected status, it can surely become the subject of politics. In an early episode in the Garfield cartoon series, Garfield, a fat striped cat, was made to say something like: 'One good thing about being a cat is, any food you touch, becomes yours.' The Holy, or what plays a key role in your culture such that it demands protection, might equally become the vehicle for a not dissimilar kind of acquisitive opportunism.

In addition, as I noted earlier, one feature of religious pluralism is that the key tenets of many religions commit their devotees to denying the claims of the devotees of other religions. It is just not clear that there can be respect and mutual tolerance, if you take the claim to the truth of your own beliefs seriously, and it is integral to your own views that the other people have got things terribly wrong.

Finally, here, although I can address this question only very briefly, there is an interesting problem concerning whether, with regard to these matters, there is an area between the private and the public. ${ }^{33} \mathrm{I}$ earlier referred to one line of argument in Foote, in which he argued that the cartoons in the Freethinker were produced for an audience of secularists, and that this should have been clear from the character of the publication. It is possible that the same might be argued, in respect of the Gay News blasphemous libel case. Here, a short poem by James Kirkup, depicted a Roman centurion expressing his love for Jesus, by means of various forms of sexual activity conducted with his just-dead body. ${ }^{34}$ It would seem as if the poem was intended to express a genuine devotion, but its public meaning was highly offensive, and Mrs Mary Whitehouse, of the British National Viewers and Listeners Association - a crusader for morality - brought a private prosecution against it for blasphemous libel, which was successful. ${ }^{35}$ One might ask, however: but should not the fact that it appeared in Gay News indicate that it was produced for, as it were, a niche market, such that those who might find this offensive would understand that it was not for them? But in this particular case, the reaction of their own readers, and that of those working on the paper towards the poem, suggested that this defence might not be open to them, ${ }^{36}$ even if it could be defended in a wider context. 
Where does all this leave us? I am initially inclined to say that, in a pluralistic setting, there is good reason for ditching the crime of blasphemy. At the same time, there is surely a case for prohibiting by law offensive behaviour that is liable to provoke a breach of the peace. At another level, it would seem to me that it is reasonable to regard as morally offensive the production of things that would deeply offend harmless people: consider, again, the deliberate violation of things that Aboriginal people hold as sacred, but now generalise this to the core concerns of others. At the very least, this should mean that we don't fete work which gives such offence, or express solidarity with it if it is criticised. This does not mean that we should silently acquiesce to calls for the death or imprisonment of those who produce it.

I said, above, that I am inclined to offer that response. But there are problems about it, not least this question of what, and to what extent, things get protection, and who gets to decide. It is surely only core concerns that should receive such protection. But who gets to decide what people's core concerns are? And does the protection that might be accorded to the core concerns of major religions, really extend to, say, the fantasies of some group of ratbags who thinks that aliens have kidnapped them a space ship, and then returned them to Earth with remarkable news for mankind?

I am left unsure about what we should do concerning these matters. One might say: be respectful of work that has a public meaning as sacred, in the cultures within which our work is produced and in which we would expect it to be disseminated. And over and above this, be mindful of the sensibilities of the vulnerable. But such a response is clearly inadequate, and I am happy to leave this problem to others, to see what they make of it.

Andres Serrano, when his Piss Christ was attacked, commented that he thought that its destruction was an act of 'desecration'. ${ }^{37}$ Clearly, I might be tempted to take any criticism of my paper in similar terms - if I were not, in these matters, influenced by Karl Popper, who stressed fallibilism and the importance of holding everything open to criticism, and who argued that it is good for us, even if we don't enjoy it.

\section{Endnotes}

${ }^{1}$ I would like to thank Geoff Stokes for conversation and for some most useful comments on a draft of this paper, from some of which I was not able to benefit on this occasion, for reasons of space, and also to David Wall and the editors for some useful criticism and suggestions.

2 On which, see Reid Mortensen, 1994, 'Blasphemy in a secular state: A Pardonable sin?', UNSW Law Journal, vol. 17, no. 2, pp. 409-31. A useful brief overview of blasphemy laws in different states and territories is provided at: http://www.caslon.com.au/blasphemyprofile2.htm.

3 Quoted by Mortensen, ibid., p. 411.

4 There is also of course the issue of blasphemy as expletive; but this I will not discuss here. For a rather different classificatory approach, see Anthony Fisher and Hayden Ramsay, 'Of Art and Blasphemy', 2002, Ethical theory and moral practice, vol. 3, pp. 137-67. 
5 Socinianism, named after Lelio Francesco Maria Sozzini (1525-1562), was a sixteenth and seventeenth century religious movement, which called into question the deity of Christ, and emphasised, by contrast, the unity of God. It is sometimes regarded as an early form of unitarianism. Deism, a loose movement influential in the seventeenth and eighteenth centuries, while accepting the existence of God and his role as a creator, rejected revealed religion in favour of a sceptical and rationalistic approach, and also rejected the idea that God subsequently intervened in his creation.

6 See, notably, Michael Hunter, 1992, "Aikenhead the Atheist": the Context and Consequences of Articulate Irreligion in the Late Seventeenth Century', in Michael Hunter and David Wootton (eds.) Atheism from the Reformation to the Enlightenment, Oxford: Clarendon Press; and also W. Cobbett, T. B. Howell et. al. (eds), 1819, A Complete Collection of State Trials, xiii, London, pp. 917-40. For background, see also the other articles in the Hunter and Wootton collection, and also J. A. I. Champion, 1992, The Pillars of Priestcraft Shaken, Cambridge: Cambridge University Press.

7 Foote's fascinating Prisoner for Blasphemy, London: Progressive Publishing, 1886, is available on the internet at: http://homepages.ihug.co.nz/ freethought/foote/blasphemy/0bcontents.htm. Foote is discussed at length in Joss Marsh, 1998, Word Crimes, Chicago \& London: University of Chicago Press. 8 Quoted in Marsh, ibid., p. 160.

9 It is reproduced in Marsh's Word Crimes, ibid., p. 142.

10 For some discussion of which, see Marsh, ibid.

11 That is to say, that aspect of Mill's views about toleration, that stems from the stress that he placed on the idea that human knowledge was fallible, that currently accepted views may not be correct, and so on.

12 See Jonathan Riley, 2005, 'J. S. Mill's Doctrine of Freedom of Expression', Utilitas, vol. 17, no. 2 , pp. 147-79.

13 It is striking from the discussion in Hunter and Wootton, that at times the production of apologias for the truth of Christianity against imagined opponents gave rise to people taking the imagined opponents' case seriously and finding it telling.

14 For critical discussion of claims to infallible knowledge in the Shi'ite tradition of Islam, compare the work of Abdolkarim Soroush, 2002. Some of his essays are available in English in his Reason, Freedom and Democracy in Islam, Mahmoud Sadri and Ahmed Sadri (eds), London etc: Oxford University Press. 15 Clearly, an argument might be made for the suppression of material on the grounds that it might mislead the immature. But it is not clear that, for example, the history of the suppression of heresy or of Jewish objections to Christianity, can really be placed in that category.

16 This oversimplifies, in that there was, historically, the recognition of a kind of pluralism within Islam, as in the milet system of the Ottoman Empire (cf.

http://www.eurozine.com/articles/2004-03-25-ivanov-en.html), and also in Christendom at such times as Jews were not being persecuted. In addition, in the period immediately after the Reformation, a system was adopted in which the religion of a country was simply settled by the choice of the ruler. 17 Cf, for example, Richard Popkin 'Jewish Anti-Christian Arguments as a Source of Irreligion from the Seventeenth to the Early Nineteenth Century', in Hunter and Wootton (eds) Atheism from the Reformation to the Enlightenment. Isaac Troki's Faith Strengthened, for example, something that it is tempting to say should be compulsory reading for all evangelical Christians, is currently difficult to obtain in printed form (although a version is now available on the internet at:

$\mathrm{http}: / /$ faithstrengthened.org/). It is striking that Hans Joachim Schoeps was able to remark in the 'Foreword to the Second Edition' of his The Jewish-Christian Argument: 'This book made its first appearance in 1937, behind closed doors, as it were, for the authorities at that time in power in Germany allowed its sale only in Jewish bookstores and to Jews. Then, when it was noticed that it was a "dangerous" book, it was prohibited completely.' See his The Jewish-Christian Argument, London: Faber, 1965, p. xiv. See also Richard Popkin, 2006, Disputing Christianity: The 400-year-old Debate over Rabbi Isaac Ben Abraham Troki's Classic Argument, Amherst, N.Y.: Humanity Books.

18 At the very least, if one is offering arguments that are supposed to convince others, this opens up the possibility of contestation; for example, to the effect that the arguments are not valid or are not telling.

${ }^{19} \mathrm{I}$ am offering this as an argument as to what follows from epistemological fallibilism, not as an interpretation of Mill. There has been argument about just what follows from Mill's own arguments, with some (for example, John Skorupski, 1989, John Stuart Mill, London: Routledge) taking the line that I am commending here, while others (for example, Jonathan Riley in his 'J. S. Mill's Doctrine of 
Freedom of Expression') argue that Mill's own argument leads to a defence of more expressive activities, such as demonstrations.

20 But where, obviously, if they offer arguments or try to convince others that they are right, they deserve everything that they get in response.

21 Compare, in this context the controversy in 2004-05 opened up by the Iranian President Mahmoud Ahmadinejad's remarks about the Holocaust. It is striking that the Pakistani academic Ijaz Hussain, in an opinion piece 'COMMENT: Who is more civilised: Iran or the West?' was able to make what read like a reasonable case for Ahmadinejad's views, by way of describing the legal suppression of dissent about the Holocaust in several countries, and providing a list of people or organisations which had questioned it. He did not, say, refer to works which contest such claims, such as Deborah Lipstadt's Denying the Holocaust (New York: Free Press, 1993), or to the various publications on the David Irving libel trial against Lipstadt in the UK. Ijaz Hussain, 2006, 'COMMENT: Who is more civilised: Iran or the West?' Daily Times, Pakistan, January 4 2006; see http://www.dailytimes.com.pk/default.asp?page=2006\%5C01\%5C04\%5Cstory_4-1-2006_pg3_5)

22 The tradition of freedom of religion in the USA seems to be taken as a freedom to live without ones religious ideas being challenged and this - or so it seemed to me when I was living there - extended to beliefs about many other matters, in a manner that contrasts with day-to-day life in Britain or Australia.

23 Clearly, what counts as another may be contentious - say, with regard to vegetarianism, or, say, the treatment of some socially unpopular minority - but on the face of it there is a difference between how something is to be appropriately handled if it is broadly socially contentious in the society in question, as compared to ones having what is very much a minority viewpoint in the society in question. (For example, pleas for vegetarianism in a society of meat eaters need to be made in journals rather than at the dinner table.) Even issues that are contentious may need to be treated in a circumspect manner: if, say, the vegetarian chooses to eat with meat eaters in a society in which there were lively divisions and debate about vegetarianism, it would hardly be appropriate for them to accompany the meal with a running commentary about sentience, slaughterhouses, and quotations from Peter Singer.

24 Cf., on this, Joseph Alleine, Alarm to unconverted sinners etc, London: Nevil Simmons, 1993 etc.

25 Alan Peshkin, 1992, 'Experience Subjectivity', Qualitative Interest Group, College of Education, University of Georgia, 1992 conference proceedings, Keynote Address.

http://www.coe.uga.edu/quig/proceedings/Quig92_Proceedings/peshkin.92.html (Viewed January 21, 2005).

26 Quoted from Foote, Prisoner for Blasphemy (see note 2).

27 The ideas of which Rushdie made use were familiar enough, and had not been thought of as particularly contentious, in discussions of Islam. See, on this, and on many of the other complexities of the Rushdie case, the discussion in Michael M.J. Fischer and Mehdi Abedi, 1990, Debating Muslims: Cultural dialogues in postmodernity and tradition, Madison, Wis: University of Wisconsin Press.

28 I have in mind here something along the lines of the view developed by Quentin Gibson and used by him and others in the context of textual interpretation in the history of political thought; cf. James Tully (ed.) 1988, Meaning and Context, Princeton: Princeton University Press.

29 Or, say, unless they were a recently arrived visitor to the country who could quite reasonably not be expected to appreciate the significance of what they were saying.

30 Quoted in Daniel Pipes, 1990, The Rushdie Affair, New York: Birch Lane Press/ Carol Publishing Group, p. 108.

31 Of course, what is offensive is something which will change over time and will also be context-dependent, which introduces further problems that I cannot even attempt to deal with, given the space at my disposal.

32 'Little Pebble' is the name of the leader of a Catholic religious group, who in 2005 was in court to answer charges relating to sexual conduct towards an under-age member of his flock. For a site which gives some indication of the charges against him, see http://users.bigpond.net.au/wanglese/pebble.htm (Viewed January 3, 2006); for the group's web page, see: http://www.shoal.net.au/ mwoa/ (Viewed January 3, 2006).

33 I would particularly like to thank Geoff Stokes for discussion on this point.

34 The poem is reproduced at http://gaytoday.badpuppy.com/garchive/events/070502ev.htm (Viewed November 3, 2005).

35 See, for a brief report,

http://news.bbc.co.uk/onthisday/hi/dates/stories/july/11/newsid_2499000/2499721.stm, which includes a picture of Mrs Whitehouse. (Viewed November 3, 2005.) 
36 It is striking, however, that from Rictor Norton's personal account of the background to the publication http://www.galha.org/glh/214/norton.html, not only was there considerable protest from within the readership of the journal, from people who found it offensive, but Norton indicates that they 'did not relish defending a poem that we frankly realized was rather sick', even if it was sincere. 37 See 'Andres Serrano talks with Judith Ahern', Photofile 53, April 1998, pp. 8-13; see p. 13. Serrano claimed that he saw it as a desecration 'not toward the mage but toward Christ himself'. But this seems to me simply an indication of the degree to which — not unlike the poet in the cinema - his personal interpretation was of kilter with the public meaning of what he had produced. 